\title{
高温機器における劣化・損傷の検出と寿命診断 Degradation/Damage Measurement and Life Assessment of High-Temperature Components
}

近年, 電力, 航空宇宙, 石油・化学などの業界では, 保安規制緩和への対応や社会的信頼性の向上, 環境負荷問題へ の取り組みがこれまで以上に求められて抢り, 信頼性と経済性の両立が大きな課題となっている。 そのため, 破壞事故 が人的, 経済的あるいは環境面で大きな損害につながる高温機器・構造物に扔いても「保守管理の最適化と高度化」が ますます重要となってきている。保守の最適化については，現在主流の保守形態である時間計画保全型を状態監視保全 型へと変更し, 保守の最適化を図るための技術的検討が盛んに試みられている。また, 保守の高度化に扎いては, リス クベースメンテナンスといった定量的なリスク評価に基づいた保守計画策定の導入が検討され，より合理的に機器延命 化を図ることに主眼が扔かれている。これら保守の最適化と高度化を有効に機能させるためには, 検查時点に打ける部 材の劣化・損傷の程度を精度高く評価し，そのデータを保守計画設計にフィードバックすることが必要とされる。しか しながら，これまでの評価精度は，例えば “Factor of 2 ” と称されているように倍・半分程度の精度であり，満足な計画設 計結果を得るのが困難な状況にある。攵のため, 劣化・損傷の状態を正確に把握するための, 適切な技術的根拠に基づ いた高品質（高精度）かつリーズナブルな新しい劣化・損傷検出技術や余寿命診断法の開発が急務となっている.

このような中，日本材料学会・高温強度部門委員会では「寿命・余寿命評価法検討作業グループ」を組織し，2000 年 には寿命・余寿命評価技術に関する報告書『高温クリープ疲労寿命評価法およびそれに基づく余寿命評価法の現状と課 題』を発刊した。さらには, これを継承し, 高精度クリープ・疲労寿命評価法の確立と非破壊評価法の開発の方向性を 新たに提示することを目的とした「損傷評価ワーキンググループ」が 2006 年に活動をはじめたところである.

本連載講座では, 高温機器に打ける劣化・損傷の検出と寿命診断という観点から, 5 回連載の講座を企画した。代表 的な高温機器としてボイラ, 蒸気タービン, 発電・航空機用ガスタービン, 石油精製・化学プラントを取り上げ, 実機 部材にて経験されている劣化・損傷，破損の実例を紹介するとともに，従来法を中心に高温機器部材に適用されている 劣化・損傷検出技術と寿命・余寿命評価法の現状と課題について概説する. また, 最終回では, 近年注目を集めている 最新の非破壊評価法と余寿命診断技術を紹介する。一連の解説を関連分野の研究者および技術者の方々のみならず，幅 広い分野の方々に読んでいただき，活発な議論を頂ければ幸いである.

\section{1. 概 説 \\ 藤 山 一 成* \\ I : Overview}

by

Kazunari FuJIYAMA *

Key words : Creep, Fatigue, Degradation, Damage, Life assessment, Non-destructive evaluation, Maintenance, High temperature components

\section{1 まえがき}

昨今, エネルギーの有効利用と $\mathrm{CO}_{2}$ 排出削減のため, プラント機器の高効率化が求められている. プラントの 高効率化は主に作動流体の高温化と高圧化によって達成 されるため, 使用される材料には耐熱性と高い高温強度

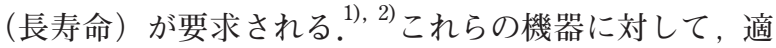
切な材料選択あるいは材料開発と, 最適設計ならびに合
理的な保守管理の確立を促進するために, 機器部材の損 傷評価・寿命診断技術の高精度化に対するニーズは従来 にも増して高まってきている.

さらに最近の研究に扔いて, 材料の計測・観察・評価 技術と解析技術が飛躍的に高度化し，原子（ナノ）レべ ルからマクロレベルまで一貫したマルチスケール評価が 可能となりつつある. ${ }^{3}$ すなわち, 基本的な物質の原理か 
らマクロ部材の損傷シミュレーションに至るまでの方法 論が整備されつつあり, 寿命診断の高精度化への適用も 可能になってきている.

一方，実機における劣化・損傷，破損などの経験にも とづく知識が蓄積されてきており，実用的な観点からの 技術の選択もなされている。すなわち，実機においては， できる限り非破壊的に高精度，簡便，適正コストでの寿 命診断が行えることが求められている. 研究開発面では, 新技術で得られた新たな知見を実用的な診断手法にどの ように結びつけていくかが重要な課題となっている.

そこで，本稿では，火力発電ボイラ，原動機打よび石 油化学プラントなどにおける非破壊計測と寿命診断に関 する講座の導入として, 実機部材の劣化・損傷の特徴と 非破壊計測・寿命診断に扎いて必要とされる技術の概要 を説明する。

\section{2 エネルギー機器の変遷と必要とされる技術}

図 1 および図 2 に, 汽力発電プラントおよびコンバイ ンドサイクル発電プラントについて，これまでの仕様の 変遷と今後の動向および今後必要とされる技術を概念的 に示す. ${ }^{5)}$ 発電機器のイノベーションには，新材料の開発 と設計技術の高度化が不可欠であるが，実際の運用にあ たっては，劣化・損傷の正確な検出に基づく精度の良い 寿命評価法を確立した上で，保守管理のための施策をと

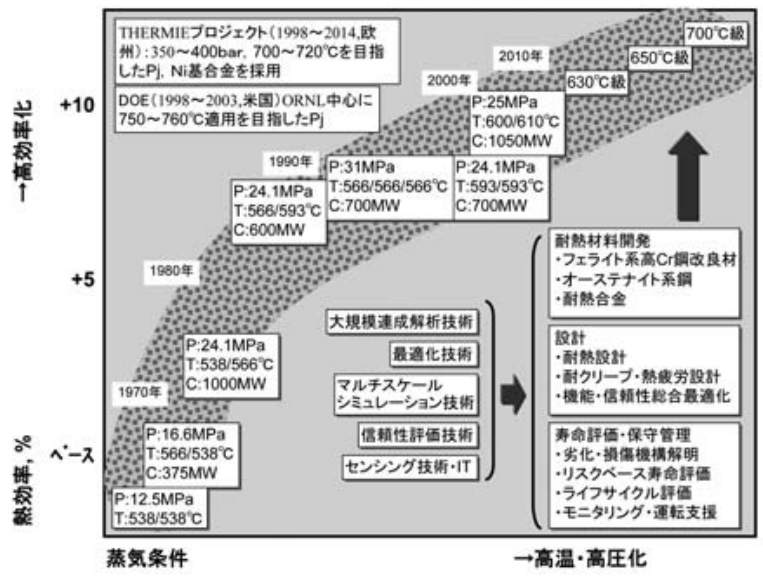

図 1 汽力発電プラントの変遷と必要とされる技術

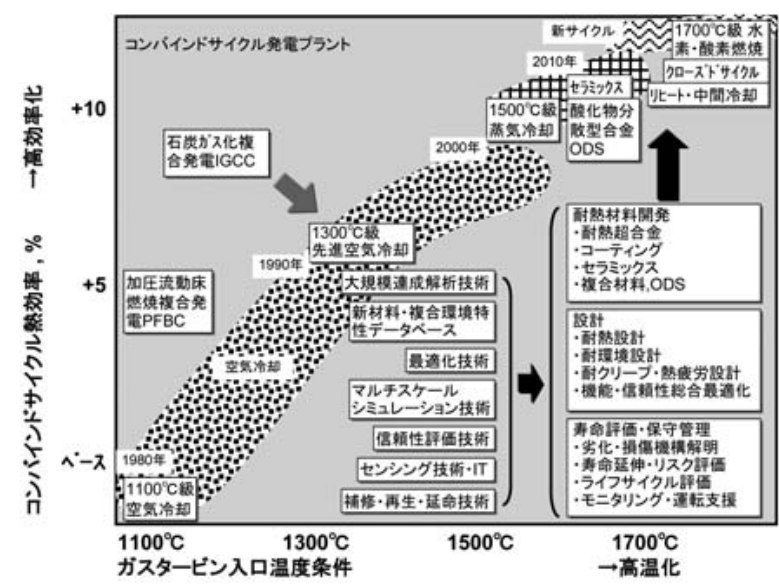

図 2 コンバインドサイクル発電プラントの変遷と必 要とされる技術
ることが重要となる。また, 保守管理情報は設計および 材料開発にフィードバックすることにより機器の改善に 活用することができる.

\section{3 高温機器における劣化・損傷の特徵と その検出・評価}

図 3 に, 高温機器に打ける劣化・損傷プロセスとその 検出・評価手段の例を模式的に示す．温度・応力などの 使用条件は, 部材の熱伝達部における酸化スケールの形 成や変形によって, 熱流体条件が変化し, 熱伝達率や熱 伝導率が変化することにより, 設計条件から冕脱してい く，例えば，加熱管内部の酸化スケールの形成は，熱伝 導率の変化をもたらし, タービン翼表面の粗さ変化は熱 伝達率の変化をもたらす。これらは使用してしばらく時 間が経過した後に現れ, 部材の使用温度を上昇させる場 合が多いことから，劣化・損傷の加速要因となる。また， 傷は，そのスケールに応じて，ナノ・サブミクロ損傷， ミクロ・メゾ損傷打よびマクロ損傷に分類することがで きる。近年, ナノ・サブミクロレベルの観察手段が飛躍 的に発達し, 従来では観察困難であった原子レベルでの 劣化・損傷の素過程を直接観察することができるように なってきた。 また，結晶格子情報をミクロレベルでマッ プとして表示できる EBSD 法などの画像化手段が普及し ており，結晶方位の情報とクリープボイドやすべり帯， 微小き裂などの関係を詳細に分析することが可能となつ てきた。これらのマルチスケール的な観察・計測手段を 対象に応じて適切に組み合わせ，損傷の実体に迫る研究 手法をハイブリッド観察手法と呼ぶこともできよう。

図 4 に，耐熱鋼（特に低合金鋼）を例にとって，劣化 と損傷の事象と概略のスケールを示す。劣化には強度低 下（軟化）とぜい化（粒界ぜい化）があり，前者はクリー プや疲労のき裂発生に至る損傷蓄積を加速し, 後者は限 界き裂寸法を低下させてき裂進展寿命を低下させる。こ

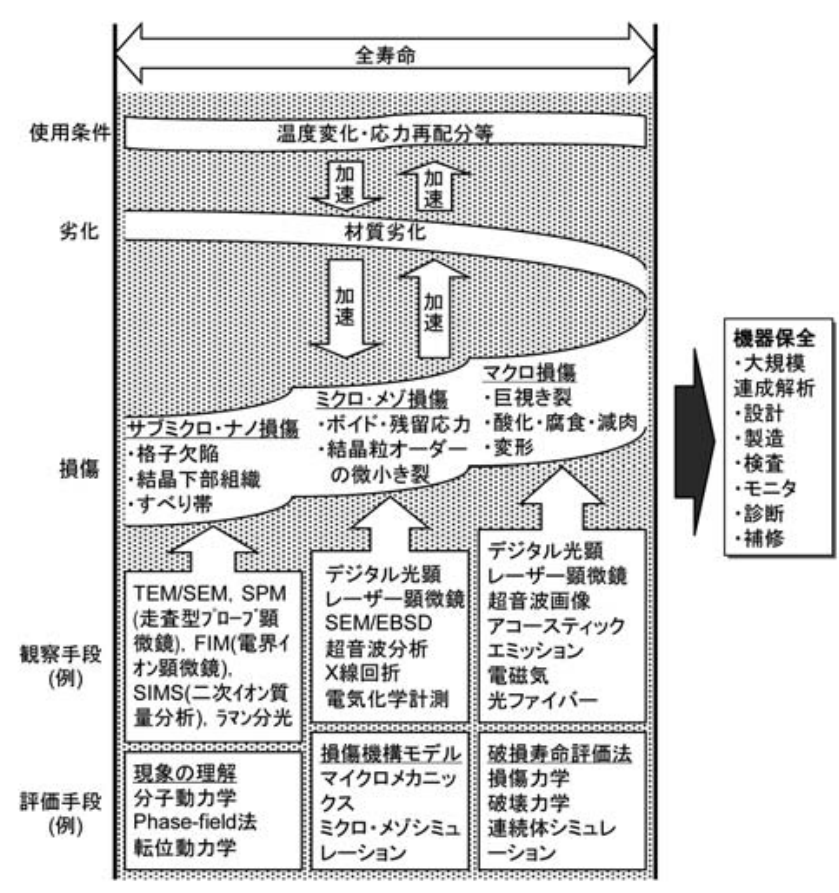

図 3 劣化・損傷の特徴とその検出・評価手段 


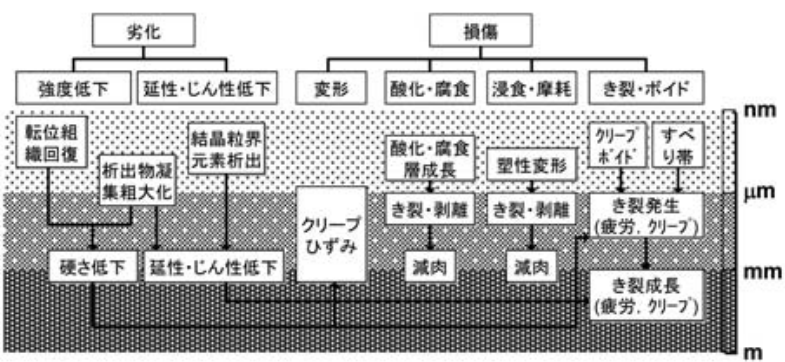

図 4 高温機器部材に生じる劣化・損傷とその相互関連

のほか, クリープ変形や損耗にかかわる現象（浸食, 摩 耗, 酸化, 腐食) も生じ, 機器の機能低下や動作不良をも たらす。以下の各節では, 実際の高温機器部材における 劣化・損傷とその計測・評価手段の例をいくつか示す?

\section{$3 \cdot 1$ 伝熱管}

困 5 に，ボイラ加熱管の断面組織の模式困と，使用条 件，劣化・損傷の形態ならびにその観察・評価手段の概 略を示す。

ボイラ加熱管は, 内部に酸化スケールが厚く堆積する ことによって, 外部からの伝熱が流体に伝わりにくくな り，管のメタル温度が上昇する。温度上昇によって, 材 料の劣化が進むが，管内には応力が分布しており，高温 で再配分している。この応力による材質劣化の加速があ り，粒界への炭化物凝集粗大化や $\sigma$ 相の析出などがみら れる，劣化は必ずしも軟化のみを意味せず，硬化し延性 低下をきたすこともある，粒界への析出物の析出は，ク リープボイドの形成の加速要因となり, クリープボイド が発生・成長しき裂となる。

観察手段としては，超音波による酸化スケール厚さ計 測, レプリカによる組織観察, 硬さ計測, 電気化学的計 測法などがある。また，クリープボイドが大きくなりき 裂が形成された場合は，超音波によって検出することも 可能である。また，ボイラでは定期検査時に抜管するこ とも可能であり, サンプルの切断調査やスモールパンチ, ミニチュアクリープなどの手段により，直接クリープ強 度や余寿命を評価することができる。

なお，石油化学プラントに扔いても，同様の内容が考 えられるが，腐食環境が一層きびしいことが特徴である。

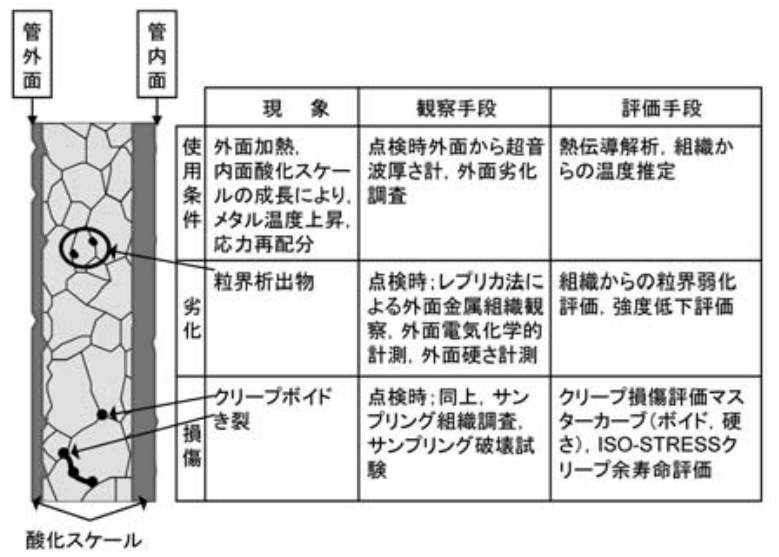

図 5 ボイラ加熱管の劣化・損傷とその観察・評価法 の例

\section{$3 \cdot 2$ ケーシング・ロータ}

図 6 に，蒸気タービン高温ケーシング（ロータにも一 部適合）の断面組織の模式困ならびに，使用条件，劣 化・損傷の形態とその観察・評価手段の概略を示す。

これらの機器は厚肉大型部品であり, かつ応力集中部 を有している，従って，起動停止などの温度変動に伴っ て篇しい熱応力の繰返しにさらされることから，比較的 頻繁に熱疲労き裂が発生する。熱疲労き裂単独では必ず しも最終破壊に至らないものの，進展後内圧応力や遠心 応力により，き裂進展が加速して破壊や板厚貫通に至る 恐机がある。また，定常運転時のクリープ応力再配分と 熱疲労による塑性の繰返しから, 応力・ひずみ条件も変 動する，さらに，材質劣化により，材料の変形特性（繰 返し応力・ひずみ特性やクリープ変形特性）も変化して 応力・ひずみ条件に影響を与える，材質劣化は低合金鋼 や高 $\mathrm{Cr}$ 鋼の場合, 転位組織の回復と粒界への炭化物の 析出による, 硬さの低下として検出される。

損傷は，表面の熱応力の繰返しに伴う熱疲労き裂の発 生と, 内部におけるクリープボイドの形成，およびクリー プ疲労条件下でのこれらの損傷の重畳が考えられる．表 面き裂の形成には表面酸化スケールも影響を及ぼす。

これらの検出に当っては，レプリカによる金属組織調 査, 硬さ計測, 電気化学的計測などにより，軟化やぜい 化などの材質劣化を検出し, 可能な場合, サンプリング によってスモールパンチやミニチュアクリープ，クリープ 疲労試験などを行い残存強度や余寿命を評価する。複雑 形状で損傷が局所に集中し，サンプル採取や非破壊計測 が困難な場合には，解析に基づく寿命評価も良く用いら れる。ボイラヘッダなどもこの範疇に含まれる。

\section{$3 \cdot 3$ 冷却翼}

図 7 に，ガスタービン動翼（静翼等高温静止部品にも 一部適合）の断面組織の模式罒ならびに，使用条件，劣 化・損傷の形態とその観察・評価手段の概略を示す.

内部冷却機器は, 定常運転時にも部材に温度勾配が生 じることから，保持サイクルの熱疲労（とくに高温時圧 縮保持サイクル）が使用条件として特徴的である。圧縮 保持サイクルでは，引張側へのリラクセーションにより， 平均応力が引張側へシフトするため, き裂が発生・進展

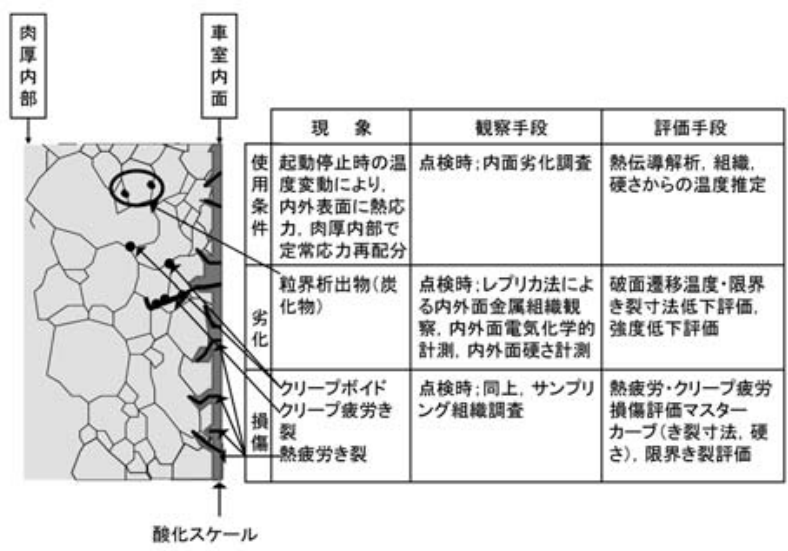

図 6 蒸気タービンケーシング・ロータ類の劣化・損 傷とその観察・評価法の例 


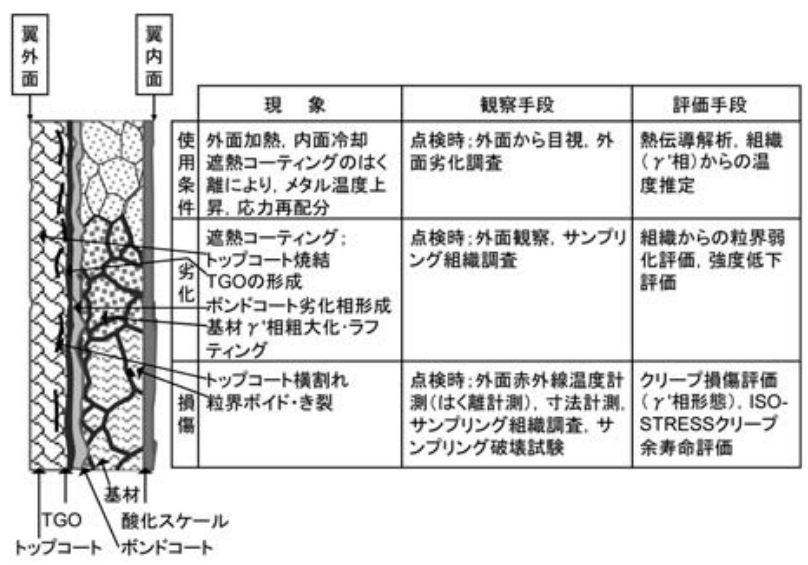

図 7 ガスタービンの劣化・損傷とその観察・評価法 の例

しやすくなる。最近のガスタービン動翼では，一方向凝 固超合金や単結晶超合金を適用して，応力方向に垂直な 粒界を無くし，かつヤング率の方位依存性を利用するこ とよって熱応力を低減させており，高温強度の向上と併 せて部材の熱疲労損傷に対する抵抗を向上させている.

また，最近の高温ガスタービンの翼にはセラミック遮 熱コーティングが施されているが，高温ガスにさらされ ることによる表面の荒れと着色は，表面での熱伝達の促 進要因となる。これは耐酸化コーティングのみを施工し た翼についても同様である。

基材の劣化は， $\mathrm{Ni}$ 基超合金の強化機構として多用され ている $\gamma^{\prime} の$ 微細析出相が高温にさらされることにより粗 大化することと, 応力方向に垂直に成長するラフティン グの形成が認められることが特徴で，いずれもクリープ 変形抵抗を減少させる方向に作用する。遮熱コーティン グの劣化は，セラミック層の焼結によって空孔が減少し， 熱応力の増大をまねくこと，七ラミックトップコートと ボンドコートの界面に $\mathrm{Al}$ や $\mathrm{Cr}$ などの酸化層 (TGO ; Thermally Grown Oxide) が成長し，体積膨張によりはく 離方向の応力を増大させること，ボンドコート層に劣化 相が生成し，基材に進行して有効断面積を減少させるこ となどがあげられる。

観察手段としては，点検時の目視，寸法計測などが有 効である.コーティングの内部はく離を検出するために, 赤外線サーモグラフィも用いられる。ささらに，サンプリ ングによる組織調査や破壊調査が有効である。ガスター ビン高温静止部品は，き裂やコーティングのはく離など を繰返し補修し，熱処理によって組織を回復させ再度使 用することから，再使用時の回復度をチェックすること も重要である。

\section{4 寿命診断と保守管理}

寿命診断技術は，火力発電設備については，ボイラと 蒸気タービンについて適用種別と適用範囲がまとめられ

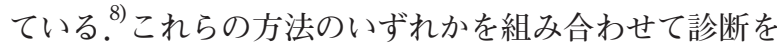
行う。そのため，より一層精度の高い手法を開発する努 力が続けられている.

困 8 にプラント機器のライフサイクル管理のための技 術を示す。運用に伴う劣化・損傷メカニズムの解明に基 ゔき，寿命・余寿命診断を行って保守管理の意思決定を
行う. 非破壊検査技術による劣化・損傷の高精度検出へ の努力は精力的に進められている，以下の各節において， 技術の現状と今後の方向についての見解を述べる.

\section{$4 \cdot 1$ 最新の観察計測手段による劣化・損傷解析の高 度化}

表 1 に，現状において良く使用されている非破壊計測 法の例を示す ${ }^{8)}$ 評価マスターカーブの対象とする材料は 低合金鋼を主に想定している。硬さ測定法は損傷の初期 に大きく変化する場合が多いため，クリープ損傷が集中 する部位を初期に検出する方法として用いることができ る。硬さは疲労損傷については単調減少の傾向があるが, ひずみ範囲依存性やバラツキが大きいため，後述の微小 き裂測定法に比べ優れているとはいえない，ボイド測定 法は, クリープ損傷の後半に感度があるため, 寿命診断 法としては有効であり, 硬さ法と併用することも効果的 である，微視き裂測定法は，疲労について損傷の広い範 囲に抢いて変化が現れる。部品の嵌合部など表面に現れ ていない部位については超音波探傷などとの併用も有効 である。また，超音波法はクリープ損傷の特に後半を検 出するのに有効である。

最近の観察・計測手段の中で，例えば EBSD 法と SPM を併用したハイブリッド観察法によれば，ボイドやすべ り帯などとその周囲の結晶構造の関係を知ることができ

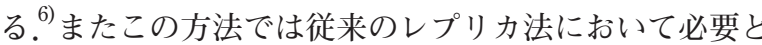

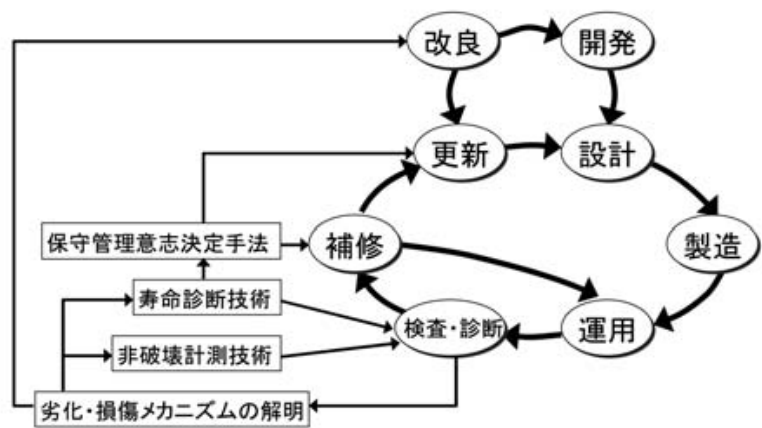

図 8 プラント機器のライフサイクル管理のための技術

表 1 従来の非破壊損傷計測法の例

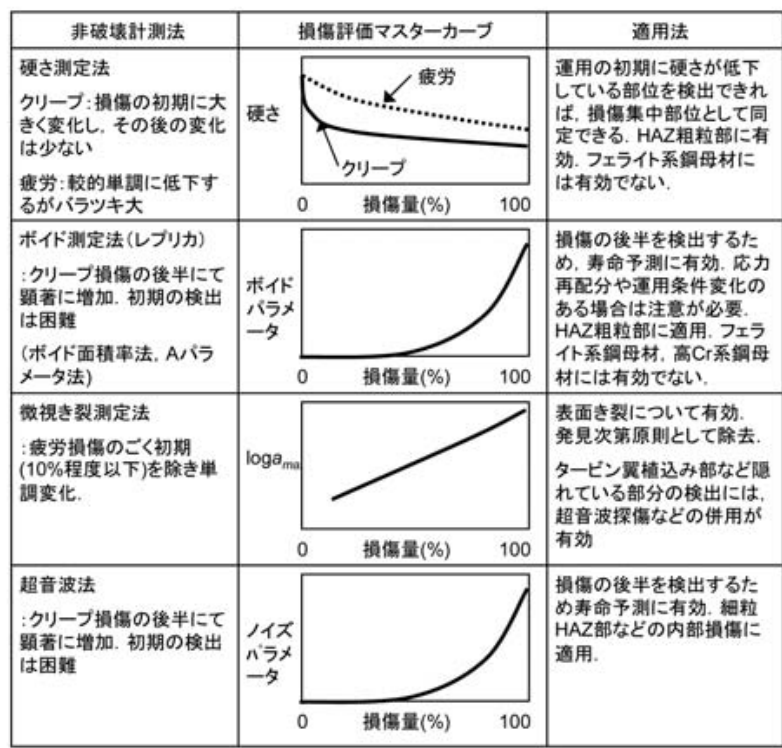


される強いエッチングを行わずとも結晶構造との関係が 明らかとなるため，ボイドや微小き裂をオリジナルに近 い形状寸法で観察することもできる。このような結晶構 造オーダーでの観察は，損傷の基本メカニズム解明のた めに用いられるが，その知識は実機における非破壊計測 の目標とする事象の絞込みにも役立ちうる.

実機からのサンプリングが可能な場合は，このような 最新手法を用いた詳細で的確な損傷評価が可能となる. また，微小サンプルを用いたスモールパンチ試験による クリープ試験法が開発され，余寿命評価法として実用化 を目指した活発な研究が行われている.

実機においては，サンプリングが難しい場合も多く， 主に非破壊計測によって劣化・損傷を検出することとな る. 先に述べたレプリカ観察, 硬さ計測や形状寸法計測 を含む目視観察などが簡便かつ実績のある方法として最 も広く用いられているが，レーザー顕微鏡を用いた光学 的計測法も開発されている.

Type IV き裂など内部損傷が寿命を支配する場合に は，超音波計測が良く用いられる。最近では信号処理技 術が進歩し，き裂以外にクリープボイド分布領域からの 信号を取り出す方法も種々提案されてきている。その結 果, クリープボイドなどの分布に詨応するパラメータも 求められるようになってきている.

\section{$4 \cdot 2$ 寿命・余寿命診断技術の高精度化}

発電用プラント機器などについては, 長年にわたり寿 命・余寿命診断の高精度化が求められてきた。しかしな がら，材料特性や実機使用条件の不確実性のために，倍 半 (Factor of 2) 以上の推定精度を求めることは極めて難 しい. Factor of 2 の範囲についても, 収集されたデータ の範囲で設定されたものが多いことから，データを多数 集積するほどその範囲を冕脱する可能性が高まる。従っ て, 統計的根拠のある寿命診断精度の設定法の確立は今 後重要な課題となるものと思われる.

実験室レベルでの推定精度の向上が進んだとしても， 実機使用条件の不確実性に伴う寿命診断精度への影響が あるため，実際に生じた損傷・破損事例を集積し，その 原因・因子別統計分析による精度の根拠ある設定が望ま れる，例えば，寿命診断に用いられるクリープと疲労に 関する損傷則については，線形損傷則とその修正則，損 傷力学的アプローチ，損傷マスターカーブ法などが主に 用いられている。実用的には，計測手法に依存した損傷 マスターカーブを作成して，実機計測結果と比較する方 法が良く用いられるが，今後は物理的根拠のある法則に よって中央特性を求め, 統計的信頼区間を設定した評価 を行っていく必要があると思われる. ${ }^{12)}$

\section{$4 \cdot 3$ 寿命・余寿命診断と合理的保守管理}

実際の機器について, 寿命・余寿命診断は次回点検時 期，補修時期と更新時期を，安全かつできるだけ低コス トになるように定めるための手段となる.

図 9 に, 寿命消費と補修との関係を蒸気タービンとガ スタービンを例にとって概念的に示す。蒸気タービンに おいては, 劣化と損傷が徐々に生じるが, 基本的に許容 限界までそのまま使用する。ガスタービンにおいては， 部品に生じる主に熱疲労損傷と材質劣化が短期間に進行
するが，これらは溶接補修や熱処理によりある程度回復 させることができるので，目標寿命まで補修を繰返しな がら使用することになる。補修と更新の判定は，主に両 者のコスト比較に基づいて判定される．従って，寿命延 伸が可能であるかどうかについて，実機部材を用いた寿 命延伸技術に関する研究が活発に行われている. ${ }^{13)}$

検査を頻繁に行うことにより，寿命診断の不確実性を 低減することができるが，コスト上昇につながることと， 検査のための分解・再組み立てなどが摺動部など機械の なじみを狂わせ，思わぬ不具合を生じさせる場合もある。 従って，分解しないで非破壊計測ができることが高頻度 の検査にとって重要である。例えば，ジェットエンジン のファイバースコープによる検査やリモート診断技術な どが参考になる. ${ }^{14)}$

保守管理計画を寿命・余寿命診断に基づき実施するこ とは合理的であるが，寿命診断の実施にはコストがかか ることから, どの部位を優先するかも重要な課題である. 近年，保守管理計画の意思決定に，事象の起こりやすさ とその影響度を掛けたリスクを指標とするリスクベース 保全の考え方が注目されて打り, ${ }^{15)}$ わが国でも石油化学プ ラントについて規格化が進められている. ${ }^{16}$

図 10 に, ボイラ, 蒸気タービン (ST), ガスタービン (GT), 石油化学プラントの高温機器について，そのリスクのお およその位置づけを示す。横軸は被害規模であるが，こ れはリスクの定義における影響度に相当する。ガスター ビンには，熱疲労き裂による損傷が比較的頻繁に生じる が，大きな被害にはつながらない。石油化学プラントで は，環境に影響を与える物質を扱う点でボイラにくらべ て被害規模は大きいと考えられる。対策については，リ スク低減と未然防止対策が考えられるが，完全な回避や 移転は難しく，保守管理の充実によってリスク低減をは かる必要がある.

\section{$4 \cdot 4$ 寿命・余寿命診断と設計}

ガスタービンには比較的頻繁に損傷が生じることから， この要因を低減する材料と設計の改善が積極的に進めら れており，改良された部材が多く生み出されている. ${ }^{17)}$ 疲労き裂の発生を抑える方法は，非弾性ひずみを低減さ せることであり，高耐力・高強度の材料に切り替えるこ と, 一方向凝固合金または単結晶合金を用いること, 構

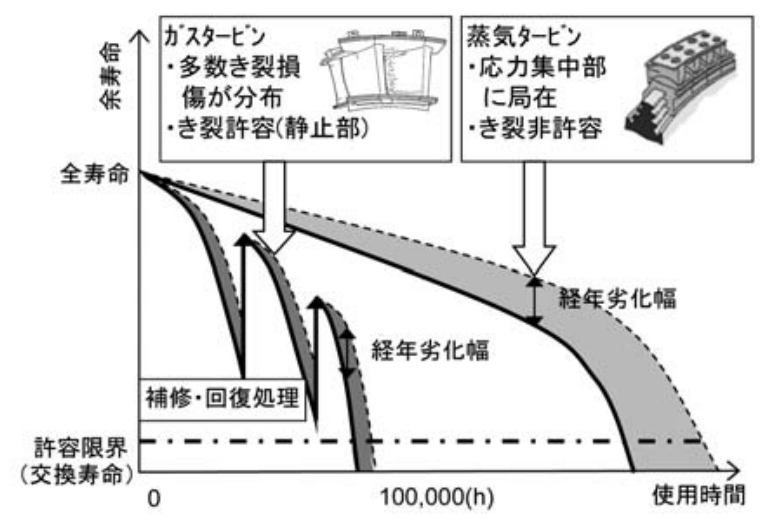

図 9 機器部材による寿命期間に対する保守管理方法 の比較 


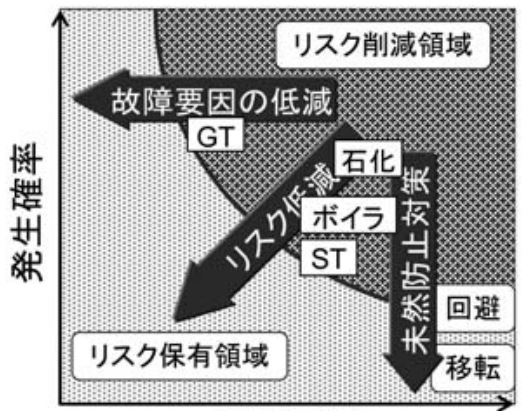

被害規模

図 10 リスクにもとづく保守管理意思決定

造の拘束を減らして熱ひずみを低減することなどの材 料・設計改善が行われている.

汽力発電の次世代 USC (Ultra-Supercritical) プラント では, クリープ強度を確保した上で，肉厚をできるだけ 薄くして熱応力の低減をはかる必要がある。また, 熱応 力対策に効果のあるフェライト系高強度耐熱鋼の開発が 積極的に進められている ${ }^{18)}$ が，超合金の使用も検討され ている.このような状況に対応した劣化・損傷の非破壊 計測技術と寿命診断技術の開発が必要となろう。

\section{5 あ と がき}

高温プラント機器における劣化・損傷の理解とその対 策については，いまだ最適解が得られているわけではない ため，事象に対する観察・計測とモデル化・シミュレー ションなどの技術を複合してさらに良い解を得る努力が 必要である。また，非破壊計測技術の実用化においても 最新の技術を取り入れた検出精度の高い方法への挑戦が 必要である。これらの分野に関して, 意欲的な研究がわ が国に扎いて活発に行われていることから，今後世界を リードする技術が多数生み出されるであろう。

\section{参 考 文 献}

1) M. Igarashi, "Advances in materials technology for fossil power plant boilers", Challenges of Heat Resistant Steels to Low Emission of $\mathrm{CO}_{2}$ in High-temperature Plants NMS-ISIJ 194/195, pp.78-98 (2008).

2 ) Y. Kadoya, "Recent progress in heat resisting steels for high efficiency power generation -steam turbine and gas turbine-", Challenges of Heat Resistant Steels to Low Emission of $\mathrm{CO}_{2}$ in High-temperature Plants NMS-ISIJ 194/195, pp.99-113 (2008).

3 ) T. Hasebe, "Bird'-eye view of recent multiscale modeling", Journal of the Japan Society of Mechanical Engineers, Vol.108, No.1043, pp.764-785 (2005).

4 ) T. Ogata, "Remaining life assessment technique for steam turbine and boiler high-temperature components", The Thermal and Nuclear Power, Vol.51, No.11 pp.1520-1534 (2000).

5 ) K. Fujiyama, "Materials and mechanics roadmaps for more efficient and more reliable electric power plant apparatus", Proceedings of the Japan Society of Mechanical Engineers No.02-11 Symposium, pp.11-16 (2002).
6) Y. Wang, H. Kimura, Y. Akiniwa and K. Tanaka, "EBSDAFM hybrid analysis on early fatigue damage in austenitic stainless steel under cyclic torsional loading”, Journal of the Society of Materials Science, Japan, Vol.55, No.10, pp.936-943 (2006).

7 ) R. Viswanathan, "Damage mechanics and life assessment of high-temperature components”, pp.265-479 (1989) ASM International.

8) K. Fujii, S. Murao, A. Tomita and K. Saito, "Residual life evaluation of thermal power plant (RET) project part 1 : introduction to residual life assessment techniques and phase I of RET project”, The Thermal and Nuclear Power, Vol.49, No.3, pp.263-279 (1998).

9) T. Kobayashi, T. Izaki, J. Kusumoto and A. Kanaya, "The application of SPC tests on high temperature materials", Proceedings of the 57the JSMS Annual Meetings, pp.357358 (2008).

10) T.Yamamoto,S.Misono, I.Nonaka and H.Usami, "Development of Creep damage Assessment System for Aged Thermal Power Plant”, Ishikawajima-Harima Gihou, Vol.37, No.6, pp.424-430 (1997).

11) T. Ohtani, "Acoustic Damping Characterization and Microstructure Evolution during Creep of a Martensitic Stainless Steel", Journal of the Society of Materials Science, Japan, Vol.56, No.2, pp.114-120 (2007).

12) Y. Takahashi and M. Yaguchi, "Evaluation of creep-fatigue life prediction methods for high-chromium ferritic steels", Proceedings of the $41^{\text {st }}$ symposium on Strength of Materials at High Temperatures”, pp.10-14 (2003).

13) Y. Yoshioka, "Evolution of repair technologies for heavyduty gas turbines high temperature components”, Journal of the Gas Turbine society of Japan, Vol.32, No.3, pp.178-182 (2004).

14) A. Yamashita, H. Aihara and A. Hasegawa, "Current status of aircraft engine maintenance and horizons", Journal of the Gas Turbine Society of Japan, Vol.33, No.3, pp.153-159 (2005).

15) K. Fujiyama, "The frontier of risk-based engineering IV : application of risk-based engineering to energy systems", Journal of the Society of Materials Science, Japan”, Vol.56, No.8, pp.781-786 (2007).

16) T. Shibasaki, "Development of HPI guide for RBI/RB (WG1), Journal of Japan High Pressure Institute, Vol.44, No.6, pp.357-361 (2006).

17) Y. Yoshioka, H. Doi, J. Takeda, K. Namba, I. Okada, K. Take and T. Ito, "Materials technology of heavy-duty gas turbine”, Journal of the Gas Turbine Society of Japan, Vol.32, No.3, pp.130-173 (2004).

18) F. Abe, "Present status of advanced high-Cr ferritic heat resistant steels for ultra-supercritical power plants”, Bulletin of the Iron and Steel Institute of Japan, Vol.11, No.4, pp.197-207 (2006). 